\title{
A Novel Neutral and Mesophilic $\beta$-Glucosidase from Coral Microorganisms for Efficient Preparation of Gentiooligosaccharides
}

\author{
Hongfei Su ${ }^{1}$, Qi Zhang ${ }^{1}$, Kefu Yu ${ }^{1,2}, * \mathbb{D}$, Chunrong Lu ${ }^{1}$, Zhenlun Xiao ${ }^{1}$, Qinyu Huang ${ }^{1}$, Shuying Wang ${ }^{3}$, \\ Yinghui Wang ${ }^{1}$, Guanghua Wang ${ }^{1}$ and Jiayuan Liang ${ }^{1}$ \\ 1 Coral Reef Research Center of China, Guangxi Laboratory on the Study of Coral Reefs in the South China Sea, \\ School of Marine Sciences, Guangxi University, Nanning 530004, China; shf2016@gxu.edu.cn (H.S.); \\ zhangqi1780@163.com (Q.Z.); chunrlu@163.com (C.L.); xzlgxu@sina.com (Z.X.); hyhqy172@sina.com (Q.H.); \\ wyh@gxu.edu.cn (Y.W.); wgh@gxu.edu.cn (G.W.); jyliang@gxu.edu.cn (J.L.) \\ 2 Southern Marine Science and Engineering Guangdong Laboratory, Zhuhai 519000, China \\ 3 School of Resources, Environment and Maters, Guangxi University, Nanning 530004, China; \\ wangshuying1910@163.com \\ * Correspondence: kefuyu@scsio.ac.cn
}

check for updates

Citation: Su, H.; Zhang, Q.; Yu, K.; Lu, C.; Xiao, Z.; Huang, Q.; Wang, S.; Wang, Y.; Wang, G.; Liang, J. A Novel Neutral and Mesophilic $\beta$-Glucosidase from Coral Microorganisms for Efficien Preparation of Gentiooligosaccharides. Foods 2021, 10, 2985. https:/ / doi.org/ 10.3390 /foods10122985

Academic Editor: Alberto Cepeda Sáez

Received: 29 October 2021

Accepted: 1 December 2021

Published: 3 December 2021

Publisher's Note: MDPI stays neutral with regard to jurisdictional claims in published maps and institutional affiliations.

Copyright: (c) 2021 by the authors. Licensee MDPI, Basel, Switzerland. This article is an open access article distributed under the terms and conditions of the Creative Commons Attribution (CC BY) license (https:// creativecommons.org/licenses/by/ $4.0 /)$

\begin{abstract}
: $\beta$-glucosidases can produce gentiooligosaccharides that are lucrative and promising for the prebiotic and alternative food industries. However, the commercial production of gentiooligosaccharides using $\beta$-glucosidase is challenging, as this process is limited by the need for high thermal energy and increasing demand for the enzyme. Here, a putative $\beta$-glucosidase gene, selected from the coral microbial metagenome, was expressed in Escherichia coli. Reverse hydrolysis of glucose by Blg163 at pH 7.0 and $40{ }^{\circ} \mathrm{C}$ achieved a gentiooligosaccharide yield of $43.02 \pm 3.20 \mathrm{~g} \cdot \mathrm{L}^{-1}$ at a conversion rate of $5.38 \pm 0.40 \%$. Transglycosylation of mixed substrates, glucose and cellobiose, by Blg163 consumed $21.6 \mathrm{U} / 0.5 \mathrm{~g}$ glucose/g cellobiose, achieving a gentiooligosaccharide yield of $70.34 \pm 2.20 \mathrm{~g} \cdot \mathrm{L}^{-1}$ at a conversion rate of $15.63 \%$, which is close to the highest yield reported in previous findings. Blg163-mediated synthesis of gentiooligosaccharides is the mildest reaction and the lowest $\beta$-glucosidase consumption reported to date.
\end{abstract}

Keywords: gentiooligosaccharides; $\beta$-glucosidase; coral microorganism; reverse hydrolysis; Transglycosylation

\section{Introduction}

The major component of gentiooligosaccharides is gentiobiose along with small amounts of gentiotriose and gentiotetraose, which are new functional oligosaccharides consisting of two or more D-glucose linked through $\beta$-1,6-glycosidic bonds [1,2]. The structural conformation of certain chemical linkages on gentiooligosaccharides enables them to be resistant to human digestive enzymes. Therefore, gentiooligosaccharides are low in terms of calories and have less chances of causing obesity, high blood lipids and pressure, diabetes, and dental caries [3]. Moreover, gentiooligosaccharides can promote the growth of Bifidobacteria and Lactobacillus as probiotics, enhance vitamin synthesis, improve metabolism, inhibit the proliferation of harmful bacteria and tumors, and promote host immune response and nutrient absorption [3-5]. One of the characteristic features of gentiooligosaccharides is hygroscopicity, which helps in maintaining moisture in food, preventing its aging, and increasing its shelf life [5]. They also improve the sensory properties of food by imparting a bitter but soft and refreshing taste; thus, they are useful as an additive and preservative in the food industry. To date, gentiooligosaccharides have been employed widely in coffee, spices, chocolate, ice cream, baking products, and dairy beverages [6].

Extraction from raw materials and enzymatic conversion are two main methods to prepare gentiooligosaccharides. The extraction method yields gentiooligosaccharides from 
the roots or stems of gentian, and bitter almond benzene. It can also be purified from the byproducts of acid-hydrolyzed starch. However, these methods are complex and inefficient, and are limited by the availability of raw materials, which is difficult to meet the high demands of industrial production. The enzymatic conversion method involves the synthesis of oligosaccharides using glucose or/and cellobiose as the substrate by the reverse hydrolysis or transglycosylation of $\beta$-glucosidase. Notably, this conversion method offers the advantages of simple operation, reduced reaction steps, easy separation and purification, and high yields [7]. However, large-scale industrial production of gentiooligosaccharides via enzymatic conversion is restricted by the high demand for the $\beta$-glucosidase enzyme.

To date, research on gentiooligosaccharide production by the enzymatic conversion method has mainly concentrated on the reverse hydrolysis of $\beta$-glucosidase that requires high levels of glucose as the raw material. $\beta$-glucosidase also displays transglycosylation activity, which is capable of synthesis of gentiooligosaccharides via the cleaving of $\beta-1,4$ glycosidic bonds of cellobiose and the transfer of substrates to glucose for $\beta-1,6$-glycosidic bond formation [8-10]. A previous study reported that a crude $\beta$-glucosidase produced by Aspergillus oryzae achieved a yield of $30.86 \mathrm{~g} \cdot \mathrm{L}^{-1}$ with cellobiose and glucose as the substrate within $72 \mathrm{~h}$ at $\mathrm{pH} 5$ and $55^{\circ} \mathrm{C}$ [11]. In other studies, recombinant $\beta$-glucosidases expressed in different microorganisms, such as Escherichia coli [1,12] and Pichia pastoris [13], were used to produce gentiooligosaccharides with transglycosylation activity. In a recent study by Wang et al., a $\beta$-glucosidase (bgl1) and a protein disulfide isomerase were co-expressed in the Pichia pastoris to synthesize gentiooligosaccharides with reverse hydrolysis, as well as transglycosylation [6]. Few studies have investigated the synthesis of gentiooligosaccharide based on $\beta$-glucosidase performed under hypothermal or mesothermal conditions.

$\beta$-glucosidases (EC 3.2.1.21) are a typical member of the cellulases that catalyze the hydrolysis of the glycosidic bonds in beta-D-glucosides and various oligosaccharides, including disaccharides, aryl- $\beta$-D-glucosides, cyanogenic glucosides, alkyl- $\beta$-D-glucosides, and other short-chain oligosaccharides, to release glucose [14]. A number of novel $\beta$ glucosidases exhibit $\beta$-galactosidase and $\beta$-xylosidase activity or reverse hydrolysis activity for the synthesis of alkyl glucosides and gentiooligosaccharides [14,15]. These enzymes are prevalent in plants, animals, including non-cellulolytic organisms, such as humans, and microorganisms, including bacteria, such as Escherichia coli, or fungi, such as Aspergillus niger and yeast $[14,16]$. There are a large number of microorganisms in coral hosts that possess a full range of cellulase enzymes, including endoglucanases, exoglucanases, and $\beta$-glucosidases, which are used to digest the surrounding plankton [17] and zooxanthellae to establish enhanced symbiotic relationships $[18,19]$. More than ten glycosidases have been found in the commensal Photobacterium mandapamensis, which are modestly induced on coral mucus and are antagonistic to the regulation of glucose, galactose mannose, arabinose, and $\mathrm{N}$-acetyl-glucosamine, relating to the defensive capability of the coral host [20]. In our previous research, the number of $\beta$-glucosidase-producing strains was more than that of protease-producing strains in corals that live at $28^{\circ} \mathrm{C}$ and harbour numerous mesophilic bacteria [21]. These results suggested that considerable amounts of $\beta$-glucosidase are ubiquitous in coral symbiotic microorganisms. However, there is no information on exploiting these enzymes from corals and their application in the food industry.

In the present study, a novel gene, blg163, was selected from the metagenomic library of coral microorganisms using high-throughput sequencing and functional screening. After successful identification and isolation, cloning and overexpression of this gene was performed to obtain the recombinant $\beta$-glucosidase, Blg163. The recombinant protein was then characterized and assessed for its application in the industrial production of gentiooligosaccharides.

2. Materials and Methods

\subsection{Strains, Vectors, and Reagents}

pEASY-E1(+) (Transgen, Beijing, China) was used to express the recombinant protein in Escherichia coli BL21(DE3) pLysS (Novagen, Darmstadt, German) as the vector. T4 
DNA ligase, E. coli Trans $5 \alpha$, restriction endonucleases, TransFast ${ }^{\circledR}$ Taq DNA polymerase and isopropyl- $\beta$-D-1-thiogalactopyranoside (IPTG) were obtained from Transgen (Beijing, China). $p$-Nitrophenyl- $\beta$-D-glucopyranoside ( $p N P G)$, gentiobiose, and cellobiose were obtained from Sigma-Aldrich (Shanghai, China). N-propanol, ethyl acetate and ammonia solution were obtained from Sangon Biotech (Shanghai, China). The DNA extraction kit was purchased from Mega (Mega Co., Ltd., Guangzhou, China). Other chemical reagents used in this study were all analytically pure unless otherwise requested. Luria-Broth comprised yeast extract $\left(5.0 \mathrm{~g} \cdot \mathrm{L}^{-1}\right)$, tryptone $\left(10.0 \mathrm{~g} \cdot \mathrm{L}^{-1}\right)$, and $\mathrm{NaCl}\left(10.0 \mathrm{~g} \cdot \mathrm{L}^{-1}\right)$, and the $\mathrm{pH}$ was maintained at 7.0, with or without supplementation with agar $\left(15.0 \mathrm{~g} \cdot \mathrm{L}^{-1}\right)$.

\subsection{Coral Sample Collection, Activity Screening, DNA Extraction, and High-Throughput Sequencing}

Coral samples collection $(10 \mathrm{~cm} \times 10 \mathrm{~cm})$ was performed at the Luhuitou coral reef $\left(109^{\circ} 28 \mathrm{E}, 18^{\circ} 13 \mathrm{~N}\right)$, located in the west of Luhuitou Peninsula, which is situated on Sanya Bay of the South China Sea, in September 2017. The surfaces of coral samples were washed gently with sterile seawater and transported immediately to the laboratory off-shore for isolation of $\beta$-glucosidase-producing bacteria according to Bruce Eberhart's protocol [22] and our previous study [21] with minor modifications. Total genomic DNA was extracted from all the strains that were screened using a DNA extraction kit, following the manufacturer's instructions, with minor modifications. Genomic DNA aliquots from the screened strains were submitted to Majorbio (Shanghai, China) for high-throughput sequencing, and the rest was preserved as a template for amplification.

\subsection{The Recombinant $\beta$-Glucosidase Blg163 Expression and Purification}

Based on gene annotation, the $\beta$-glucosidase gene blg163 was selected and amplified using the primer pair of 5'-GCATGGAATTCTGGTGACAAAAGACATTAAAGCTCTTATT TCTCAGATGA-3' (EcoR I digestion site underlined) and 5'-CCTCCGCTCGAGTTTCACA ACAGGATTCTTCTGTACCTCATTTAACT-3' (Xho I digestion site underlined). Then, the PCR product was cloned in the doubly digested pEASY-E1(+) empty vector to generate the recombinant plasmid pEASY-blg163, which was transformed into E. coli DH5 $\alpha$. The purified recombinant plasmids were subsequently transformed into E. coli BL21(DE3) pLysS for target protein expression. The transformed cells carrying pEASY-blg163 were inoculated in LB medium supplemented with ampicillin $(100 \mu \mathrm{g} / \mathrm{mL})$ at $37^{\circ} \mathrm{C}$. When the $\mathrm{OD}_{600}$ of the cultured bacterial cells reached $0.5 \sim 0.6,0.6 \mathrm{mM}$ of IPTG was added for further induction at $22{ }^{\circ} \mathrm{C}$. Then, induced cells were harvested for $16 \mathrm{~h}$, washed twice with phosphate buffered saline (PBS buffer, $\mathrm{pH} 7.0$ ), and lysed by ultrasonication (120 W, $4 \mathrm{~s}$ ) on ice for $25 \mathrm{~min}$. The lysate was centrifuged at $8200 \times g$ and $4{ }^{\circ} \mathrm{C}$ for $20 \mathrm{~min}$. The supernatant was loaded onto a $\mathrm{Ni}^{2+}$-NTA agarose gel column for enzyme purification. Elution buffer $(0.3 \mathrm{M} \mathrm{NaCl}, 0.2 \mathrm{M}$ imidazole, and $20 \mathrm{mM}$ Tris- $\mathrm{HCl}, \mathrm{pH}$ 7.9) was used to elute the protein and then was diluted three times with $4{ }^{\circ} \mathrm{C}$ deionized double-distilled $\mathrm{H}_{2} \mathrm{O}$. The purified protein was analyzed using sodium dodecyl sulfate-polyacrylamide gel electrophoresis (SDS-PAGE). Determination of the protein concentration was according to the Bradford method with bovine serum albumin as the standard [23].

\subsection{Activity Assay of $\beta$-Glucosidase}

The enzyme activity of the recombinant $\beta$-glucosidase was determined using $p$ NPG as the substrate according to previous report [24]. In brief, the reaction mixture contained $10 \mu \mathrm{L}$ of appropriately diluted enzyme, $15 \mu \mathrm{L}$ of $25 \mathrm{mM} p \mathrm{NPG}$, and $175 \mu \mathrm{L}$ of $0.2 \mathrm{M}$ citrate buffer (pH 7.0). After incubation at $30^{\circ} \mathrm{C}$ for $5 \mathrm{~min}$, the reaction was terminated by $0.1 \mathrm{M}$ $\mathrm{Na}_{2} \mathrm{CO}_{3}$. The amount of $p \mathrm{NP}$ released was determined by measuring the absorption of the reaction mixture at $405 \mathrm{~nm}$ by spectrometer (Thermo Fisher Scientific Oy, Ratastie 2, FI-01620 Vantaa, Finland). A sample which was added $100 \mu \mathrm{L}$ of $1 \mathrm{M} \mathrm{Na}_{2} \mathrm{CO}_{3}$ before the addition of the enzyme was set as control. The amount of enzyme that hydrolyzes $1 \mu \mathrm{mol}$ of $p$ NPG per min under the experimental conditions described above was defined as one unit of $\beta$-glucosidase activity (U) [25]. To determine the kinetic parameters of the $\beta$-glucosidase, 
such as $K m$ and Vmax, $p$ NPG, cellobiose, or gentiandisaccharide were prepared in a range of concentrations $(0.25-2.5 \mathrm{mM})$ in citrate buffer $(\mathrm{pH} 7.0)$ and were incubated with the enzyme at $30^{\circ} \mathrm{C}$ for $5 \mathrm{~min}$ [26]. The conditions for starting and stopping the reaction were set as same as mentioned earlier.

\subsection{Characterization of Purified Blg163}

Purified Blg163 was characterized using $p$ NPG as the substrate. Synthesis of gentiooligosaccharides was detected using glucose and cellobiose as substrates. The optimal $\mathrm{pH}$ for the enzymatic reaction was determined using buffers with different $\mathrm{pH}$ from 3.0 to 11.0 at $30^{\circ} \mathrm{C}$ ( $\mathrm{pH} 8.0-11.0$ with $0.05 \mathrm{M}$ glycine- $\mathrm{NaOH}$ buffer, $\mathrm{pH} 3.0-8.0$ with $0.2 \mathrm{M}$ McIlvaine buffer). The optimum temperature for enzymatic reaction was determined to be from $0{ }^{\circ} \mathrm{C}$ to $70{ }^{\circ} \mathrm{C}$ in a buffer with $\mathrm{pH}$ 7.0. The residual activity of the enzyme was measured after incubating the enzyme at different temperatures from $0{ }^{\circ} \mathrm{C}$ to $70^{\circ} \mathrm{C}$ for $1 \mathrm{~h}$ to determine the thermal stability of recombinant Blg163. To investigate the effects of different metal cations on the enzyme activity, $1 \mathrm{mM}$ and $10 \mathrm{mM}$ (final concentration) of $\mathrm{Mg}^{2+}, \mathrm{Li}^{+}, \mathrm{Na}^{+}$, $\mathrm{K}^{+}, \mathrm{NH}_{4}{ }^{+}, \mathrm{Ca}^{2+}, \mathrm{Fe}^{3+}, \mathrm{Ba}^{2+}, \mathrm{Zn}^{2+}, \mathrm{Ni}^{2+}, \mathrm{Cu}^{2+}, \mathrm{Co}^{2+}$, diamine tetra-acetic acid (EDTA), and sodium dodecyl sulfate (SDS) were added to the reaction system individually. The effect of glucose and ethanol on enzyme activity was investigated by measuring the residual activity at different final concentrations $(0 \%, 5 \%, 10 \%, 15 \%$, and $20 \%$ glucose; $0 \%, 5 \%, 10 \%$, $15 \%, 20 \%, 25 \%$, and $30 \%$ ethanol). The sample with PBS (pH 7.0) was used as the control. All enzyme activities were determined by three repeated experiments.

\subsection{Gentiooligosaccharide Production via $\beta$-Glucosidase-Mediated Reverse Hydrolysis with Glucose}

Gentiooligosaccharide synthesis was initiated in a total volume of $2 \mathrm{~mL}$ in an orbital shaker (Tsc $24 \times 2.0 \mathrm{~mL}$, Biometra, German) at $150 \mathrm{rpm}$. To evaluate the effect of temperature and $\mathrm{pH}$ on yield of gentiooligosaccharides, enzymatic reactions were conducted at a $\mathrm{pH}$ ranging from 5.0 to 8.0 and temperatures ranging from 25 to $45{ }^{\circ} \mathrm{C}$ in $50 \mathrm{mM}$ Mcllvaine buffer ( $\mathrm{pH} 7.0)$ dissolving 20\% (w/v) glucose with $40 \mathrm{U}$ of enzyme. The effect of glucose concentration on the yield of gentiooligosaccharides was studied at the optimal $\mathrm{pH}$ and temperature with different glucose concentrations (5-50\%) incubated with $40 \mathrm{U}$ of the enzyme. The effect of enzyme concentration on the yield of gentiooligosaccharides with $10,20,30,40$, and $100 \mathrm{U} / \mathrm{g}$ of glucose or $\mathrm{U} / 0.5 \mathrm{~g}$ cellobiose was investigated under optimal conditions.

\subsection{Gentiooligosaccharide Synthesis Using Glucose and Cellobiose via Transglycosylation}

Cellobiose and glucose as the donor and acceptor, respectively, were used to produce gentiooligosaccharides. The gentiooligosaccharide synthesis was carried out in $50 \mathrm{mM}$ citrate buffer ( $\mathrm{pH} 7.0$ ) at $30^{\circ} \mathrm{C}$. The effects of molar ratio of substrate (glucose:cellobiose $=1: 2$, $1: 1,2: 1$, and 4:1), substrate concentration (glucose + cellobiose $=5 \%+20 \%, 10 \%+20 \%$, $10 \%+10 \%, 20 \%+10 \%, 25 \%+12.5 \%, 30 \%+15 \%, 50 \%+25 \%$, and $60 \%+30 \%$ ), and enzyme concentration $(3.6,7.2,14.4,21.6,28.8$, and $36 \mathrm{U} / \mathrm{g}$ of glucose) on the yield of gentiooligosaccharides were determined under optimal conditions. Samples were taken at different time intervals and immediately boiled for $10 \mathrm{~min}$ for high performance liquid chromatography (HPLC) analysis.

\subsection{Thin-Layer Chromatography (TLC) and High-Performance Liquid Chromatography Analysis of Gentiooligosaccharides Produced by Blg163}

The synthesis of gentiooligosaccharides was carried out by transglycosylation reaction under optimal conditions, as described above. The resulting samples were analyzed using thin-layer chromatography (TLC silica gel G25, Merck, Drmstadt, Germany). The mobile phase for the TLC comprised n-propanol, ammonia solution, ethyl acetate, and water $(6: 3: 3: 1, v / v)$. The spots of the samples were visualized with iodine vapor [27]. For assessment of the yield of gentiooligosaccharides, the resulting samples were filtered through a $0.22 \mu \mathrm{m}$ syringe filter (Merck Millipore Ltd., Drmstadt, Germany), and $20 \mu \mathrm{L}$ of filtrate was injected into HPLC at $40{ }^{\circ} \mathrm{C}$ by a 1260 Infinity II pump, and exposed to a 
G7102A evaporative light scattering detector (ELSD) (Agilent Technologies, Inc., Santa Clara, CA, USA) equipped with Spherisorb Amino $\left(\mathrm{NH}_{2}\right)$ column $(4.6 \mathrm{~mm} \times 250 \mathrm{~mm}$, $80 \AA, 5 \mu \mathrm{m}$ ) (Cosmosil, Kyoto, Japan). The mobile phase for HPLC consisted of $25 \%$ MilliQ water and $75 \%$ acetonitrile with a flow rate of $1.0 \mathrm{~mL} / \mathrm{min}$. The retention time of glucose, cellobiose, gentiooligosaccharides was $10.5 \pm 0.2,16.0 \pm 0.2,19.5 \pm 0.2 \mathrm{~min}$, respectively, and the calibration curve concentration ranged from 1.00 to $10.00 \mathrm{mg} / \mathrm{mL}$. The maximal enzyme conversion was defined as $100 \%$, and the relative conversion rate for each reaction was calculated accordingly. All analyses were performed in triplicate.

\subsection{Bioinformatic Analysis and Nucleotide Sequence Submission}

The nucleotide sequence of the $\beta$-glucosidase gene, blg163, was deposited in GenBank (https:/ / www.ncbi.nlm.nih.gov/genbank/ (accessed date: 6 March 2020)) with accession number (MT797857). The three-dimensional structure of Blg163 was predicted by homology modeling (https:/ / swissmodel.expasy.org/ (accessed date: 28 May 2020)) [24]. DNA and protein statistics were analyzed using the algorithms of the sequence-manipulation suite. The signal peptide and catalytic domain of the protein were predicted by the online SMART tool (http://smart.embl-heidelberg.de/ (accessed date: 6 March 2020)). Multiple amino acid sequences of proteins were aligned using the ENDscript server (http:/ / espript.ibcp.fr/ESPript/ESPript/ (accessed date: 9 April 2021)) [28] and ClustalX.

\section{Results}

\subsection{Cloning, Expression, and Purification of $\beta$-Glucosidase}

Approximately 264 different $\beta$-glucosidase-producing strains were obtained from coral, and their metagenome sequencing and annotation were carried out. From the metagenome analysis, a candidate $\beta$-glucosidase gene, blg163, was identified. This gene was cloned into pEASY-E1(+) and expressed in Escherichia coli BL21(DE3) pLysS strain. A complete open reading frame of $1341 \mathrm{bp}$ in the putative $\beta$-glucosidase gene shared the highest identity $(80 \%)$ with a gene without annotation from Celeribacter ethanolicus strain TSPH2. This gene encodes a polypeptide with 447 amino acid residues that showed the highest amino acid sequence identities of $95.3 \%, 94.6 \%, 83.2 \%$, and $74.4 \%$ with putative proteins from the genome of Rhodobacteraceae bacterium, Celeribacter sp. HF31, Rhodobacteraceae bacterium, and Pacificibacter maritimus, respectively (Figure 1), which have not so far been characterized. The amino acid residues from Met1 to Ser447 of the Blg163 protein resembled the catalytic domain of the glycosyl hydrolase family 1 (GH1) proteins.

$\beta$-glucosidase expression was induced by adding IPTG $(0.6 \mathrm{mM})$ to the culture when $\mathrm{OD}_{600 \mathrm{~nm}}$ reached 0.5 at $160 \mathrm{rpm}$ and $22^{\circ} \mathrm{C}$ for $16 \mathrm{~h}$. The cell lysate was applied to a $\mathrm{Ni}^{2+}-$ NTA agarose and washed out with an imidazole gradient of $200-300 \mathrm{mM}$. The purified protein was subjected to SDS-PAGE, and a single protein band appeared clearly at $54.3 \mathrm{kDa}$ (Figure 2A), which was consistent with the theoretical molecular weight. The eluted fraction was tested for its activity and was demonstrated to be $465 \pm 5.6 \mathrm{U} \cdot \mathrm{mL}^{-1}$ product generation. Compared to other over-expressed $\beta$-glucosidases, such as, the $\beta$-glucosidase from $A$. niger AS3.4523, which exhibited high activity $\left(25.88 \pm 0.45 \mathrm{U} \cdot \mathrm{mL}^{-1}\right)$ [29], Blg163 was successfully expressed in Escherichia coli BL21 (DE3) pLysS.

Blg163, $\beta$-glucosidase from coral microorganism in this study; $R$. $b$. NVK46632.1, $\beta$ glucosidase from Rhodobacteraceae bacterium; C. sp. WP_167600635.1, $\beta$-glucosidase from Celeribacter sp. HF31; R. b. TNE64695.1, $\beta$-glucosidase from Rhodobacteraceae bacterium; P. m.WP_123791906.1, $\beta$-glucosidase from Pacificibacter maritimus. The similar and conserved amino acids of $\beta$-glucosidases were indicated with solid and black boxes, respectively. 


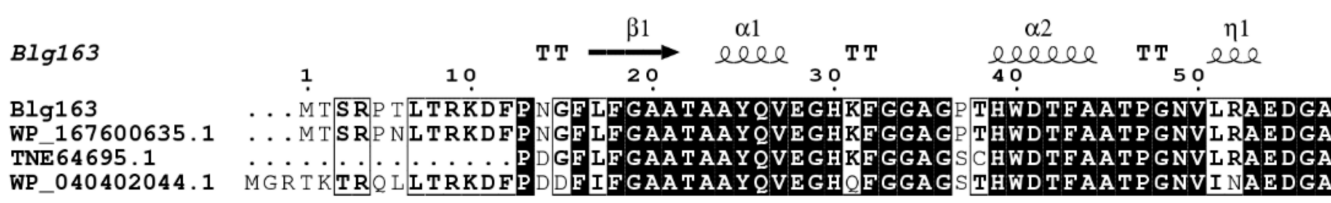

BIg163

Blg163

WP_167600635.1

TNE 64695.1

WP_040402044.1
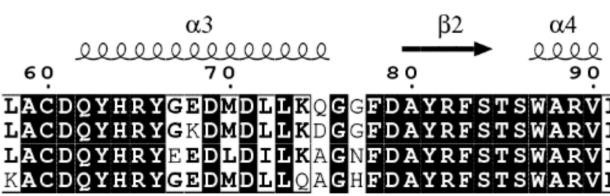

$\alpha 5$

DAYRFSTSWARVIPTGRG

作

FDAYRFST SWARVIPEGRG VNOEGLDYYDRLTDAILERG

$\operatorname{Blg} 163$

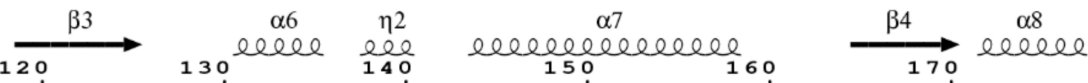

Blg163 LEP HLT LYHWEMP A ALS DLGGWTNPDVH L WF GDFVEI DD KIGDRMATVATINE PWCVSY

WP_167600635.1 LEPHLTLYHWE

TNE 64695.1

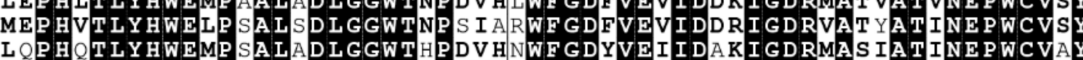

WP_040402044.1 LQPHQTLYHWE

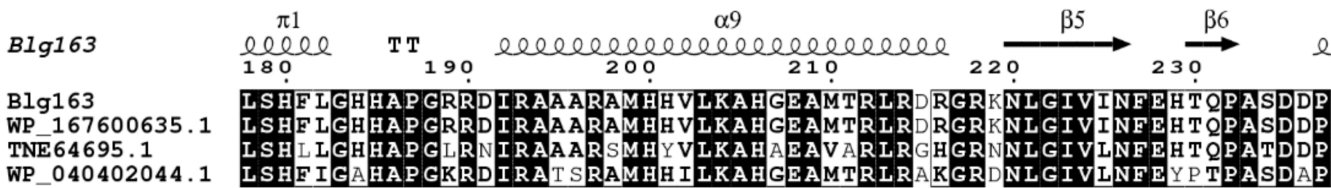

$\operatorname{Blg} 163$
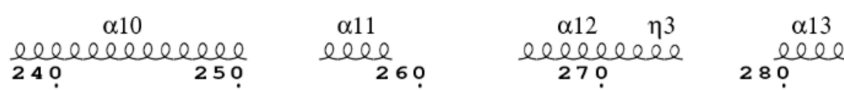

290

Blg163

WP 167600635.1

KD IKAAATQDAT NNRWF IEAIAKGKYPHEALEGLEPHL

TNE 64695.1

RD IRAAATQDATH HRWF I EAIAKGRYP

EA LA GLEPHLPK GWODDM A IS OP I WL GV

WP_040402044.1

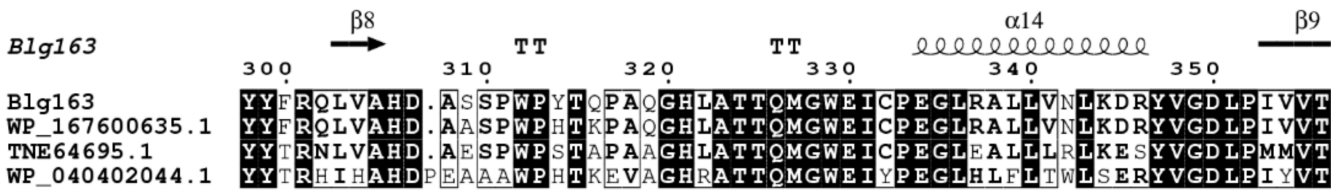

TNE64695.1

WP 040402044.1

Blg163

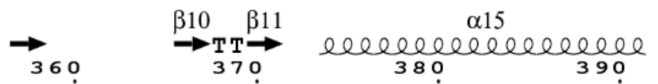

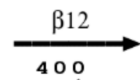

410 eleeee

Blg163

WP_167600635.1

INGMAWDDQVRNGVVHDPE

TNE64695.1 ENGMAWDDHVRNGVV

WP_040402044.1

Blg163

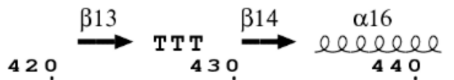

Blg163

430

44

WP_167600635.1 RRFGIVHVDFETLORT PKASYHMLKDMI ARS

TNE 64695.1 RRF GIVHVDFE T LKRT P KA SYHMLK L L E R

WP_040402044.1 KRFGIVHVDFETLQRT P KASYHMFKDILTRS

Figure 1. Alignment of amino acid sequence of Blg163 with other $\beta$-glucosidases. 


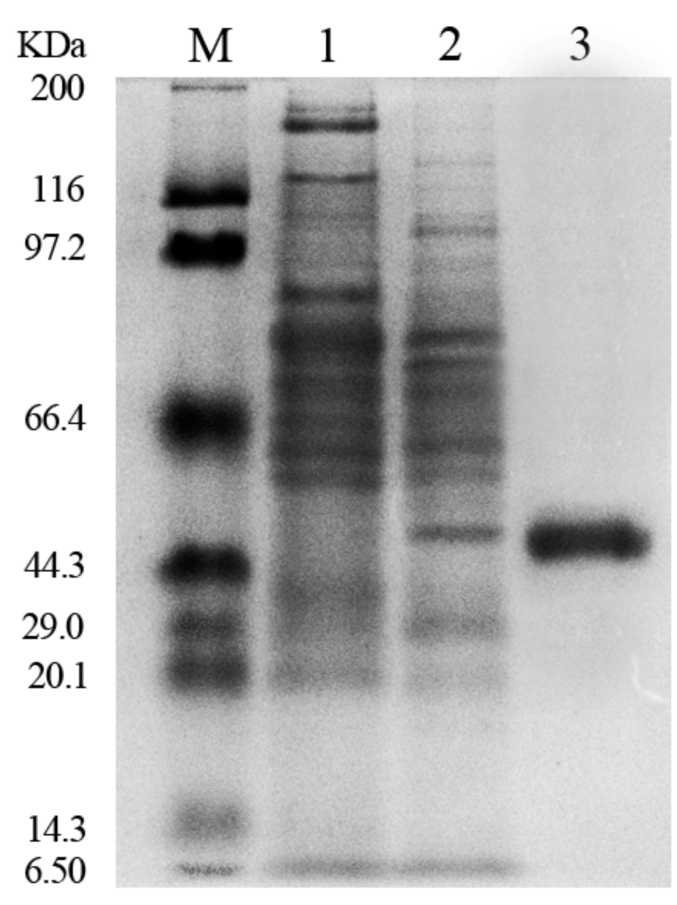

(A)

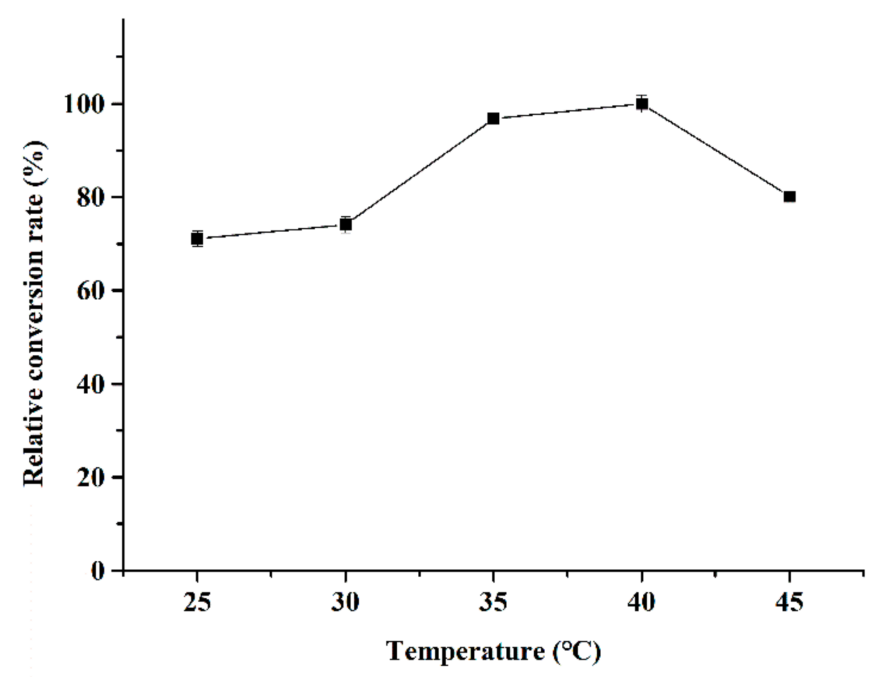

(B)

Figure 2. SDS-PAGE analysis of the purified Blg163 (A). M protein marker; 1 recombinant Escherichia coli BL21(DE3) harboring pEASY-E1(+) induced with IPTG; 2 recombinant Escherichia coli BL21(DE3) harboring pEASY-E1(+)—Blg163 induced with IPTG; 3 purified Blg163. Effects of temperature on gentiooligosaccharide production (B). The reactions were launched in $50 \mathrm{mM}$ citrate buffer (pH 7.0) at $25-45^{\circ} \mathrm{C}$ with $30 \%$ glucose and $15 \%$ cellobiose.

\subsection{Enzymatic Properties of Recombinant $\beta$-Glucosidase}

Blg163 functioned at an optimal temperature of $30^{\circ} \mathrm{C}$. Moreover, the enzyme maintained its activity up to $35.2 \%$ at $10^{\circ} \mathrm{C}$. The enzyme retained $>95 \%$ residual enzyme activity after incubation at $0-30{ }^{\circ} \mathrm{C}$ for $1 \mathrm{~h}$ (Figure S1), indicating that it is a cold-active enzyme. Blg163 displayed $>90 \%$ residual activity between $\mathrm{pH}$ 6.0-7.0 and demonstrated the highest activity at $\mathrm{pH} 7.0$, retaining $>95 \%$ residual enzyme activity after incubation at $\mathrm{pH} 5.0-8.0$ for $1 \mathrm{~h}$ (Figure S2), indicating that it is a neutral enzyme. This finding differs from the previously reported $\beta$-glucosidases, such as HML0366 (pH 5.0) [11], RmBglu3B [13], and Bgl1 ( $\mathrm{pH}$ 5.0) [6]. The optimum reaction temperature and $\mathrm{pH}$ of Blg163 were confirmed to be $30^{\circ} \mathrm{C}$ and 7.0, indicating that this enzyme is a mesophilic and neutral $\beta$-galactosidase. Blg163 exhibited $>40 \%$ of maximum activity with the existence of $5-20 \%$ glucose (Figure S3) and retained $>50 \%$ residual enzyme activity undergoing $15 \%$ ethanol incubation (Figure S4), signifying its high tolerance to ethanol and glucose.

The purified recombinant enzyme displayed a peak specific activity of $29.74 \pm 2.7$ and $28.0 \pm 2.3 \mathrm{U} \cdot \mathrm{mg}^{-1}$ for $p$ NPGlu and cellobiose (Table S1), respectively. The kinetic parameters of Blg163 for $p$ NPG, cellobiose, and gentiobiose were measured at the optimum reaction temperature and $\mathrm{pH}$. The $\mathrm{Km}$ values for $\mathrm{pNPG}$, cellobiose, and gentian disaccharide were $0.32,0.45$, and $0.72 \mathrm{mM}$ (Table S1), respectively. These results indicate that Blg163 has a higher substrate affinity for $p$ NPGlu than for cellobiose and gentiobiose.

\subsection{Gentiooligosaccharide Production from Cellobiose and Glucose}

Gentiooligosaccharides are widely applied in food processing as they are indigestible [3] and excellent prebiotics [4], can retain moisture, and have a soft, refreshing, bitter taste [6]. It is very important to develop a cost-effective method that achieves mild reaction conditions and simple isolation techniques for preparation of gentiooligosaccharides via enzyme catalysis for the food industry [30]. Some $\beta$-glucosidases have been shown to have trans- 
glycosylation activity which facilitates the synthesis of gentiooligosaccharides. These enzymatic processes have the advantages of strong specificity, mild reaction conditions, high catalytic efficiency, and easy isolation from the product mixture [31,32]. The reported $\beta$-glucosidases, using a high concentration of glucose as the substrate, can transfer free glucose to other sugar substrates by forming $\beta-1,6$-glycosidic bonds, thereby synthesizing oligosaccharides $[8,33,34]$.

The effect of glucose concentration on the yield of enzymatic catalysis was determined, after an appropriate amount of $\beta$-glucosidase was assimilated to the reactions under optimal $\mathrm{pH}$ and temperature $\left(\mathrm{pH} 7.0\right.$ and $\left.40{ }^{\circ} \mathrm{C}\right)$, with various concentrations of glucose as the substrate. When the glucose concentration reached $30 \%$, the conversion rate of gentiooligosaccharides gradually increased with an increase in the concentration of glucose (Table 1). However, when the glucose concentration was higher than $60 \%$, the output of gentiooligosaccharides no longer improved further, and was replaced by a slow reduction, presumably because the reverse hydrolytic activity of $\beta$-glucosidase began to be inhibited by free glucose above this concentration. Furthermore, the demand for the enzyme was more than $400 \mathrm{U} \cdot \mathrm{g}^{-1}$ of glucose, which is consistent with a previous report that required high enzyme consumption (900 $\mathrm{U} \cdot \mathrm{g}^{-1}$ of glucose) [6]. This result indicates that the preparation of gentiooligosaccharides by Blg163-mediated reverse hydrolysis may be an inefficient way of transformation using glucose as a single substrate.

Table 1. Output of gentiooligosaccharides $\left(g \cdot \mathrm{L}^{-1}\right)$ with different concentrations of glucose.

\begin{tabular}{|c|c|c|}
\hline Glucose Concentration & $\begin{array}{l}\text { Yields } \\
\left(\mathrm{g} \cdot \mathrm{L}^{-1}\right)\end{array}$ & $\begin{array}{c}\text { Conversion Rate } \\
(\%, w / w)\end{array}$ \\
\hline $80 \%$ glucose & $43.02 \pm 3.20$ & $5.38 \pm 0.40$ \\
\hline $70 \%$ glucose & $42.25 \pm 4.21$ & $6.07 \pm 0.60$ \\
\hline $60 \%$ glucose & $40.50 \pm 3.20$ & $6.75 \pm 1.12$ \\
\hline $50 \%$ glucose & $35.34 \pm 2.60$ & $7.07 \pm 0.52$ \\
\hline $40 \%$ glucose & $28.21 \pm 2.72$ & $7.05 \pm 0.68$ \\
\hline $30 \%$ glucose & $17.38 \pm 0.78$ & $5.79 \pm 0.26$ \\
\hline $20 \%$ glucose & ND & $\mathrm{ND}$ \\
\hline $10 \%$ glucose & ND & ND \\
\hline
\end{tabular}

$\mathrm{ND}$, not detected.

$\beta$-glucosidase-mediated transglycosylation using a mixed substrate of cellobiose and glucose was adapted for gentiooligosaccharide synthesis. The yield of gentiooligosaccharides first increased and then decreased with an increase in reaction temperature, peaking at $40^{\circ} \mathrm{C}$ (Figure 2B). The optimum $\mathrm{pH}$ for gentiooligosaccharide production was $\mathrm{pH} 7.0$. More than $70 \%$ yield was retained at $\mathrm{pH}$ ranging from 6.0 to 8.0 (Figure $3 \mathrm{~A}$ ). As far as we are aware, Blg163 is the first neutral and mesophilic $\beta$-glucosidase that exhibits efficient oligosaccharide synthesis activity. This is distinctly different from other $\beta$-glucosidases as their optimal temperature and $\mathrm{pH}$ for gentiooligosaccharide production were higher than $50^{\circ} \mathrm{C}$ and $\mathrm{pH} 5.0$, respectively $[6,11,13]$. These results indicate that Blg163-mediated gentiooligosaccharide synthesis is simple, cost-effective, and energy-saving without the need for high temperature and sophisticated equipment. All these features highlight the potential application of Blg163 in the food industry for the commercial production of gentiooligosaccharides.

Compared with a single substrate, the mixed substrate of glucose and cellobiose resulted in greater productivity. The peak yield of gentiooligosaccharides was attained at $70.3 \mathrm{~g} \cdot \mathrm{L}^{-1}$ when the molar ratio of glucose to cellobiose was $4: 1(30 \%$ glucose $+15 \%$ cellobiose).Steps to increase the proportion of glucose led to a slight rise in the production of gentiooligosaccharides (Table 2). However, the cost price of glucose is higher than that of cellobiose. Thus, the most appropriate molar ratio of glucose to cellobiose can be inferred to be $4: 1$ to balance yield and cost. Our novel $\beta$-glucosidase is different from Trichoderma viride $\beta$-glucosidase, which attained the highest yield of gentiooligosaccharides with a glucose to cellobiose molar ratio of 1:1 [6]. 


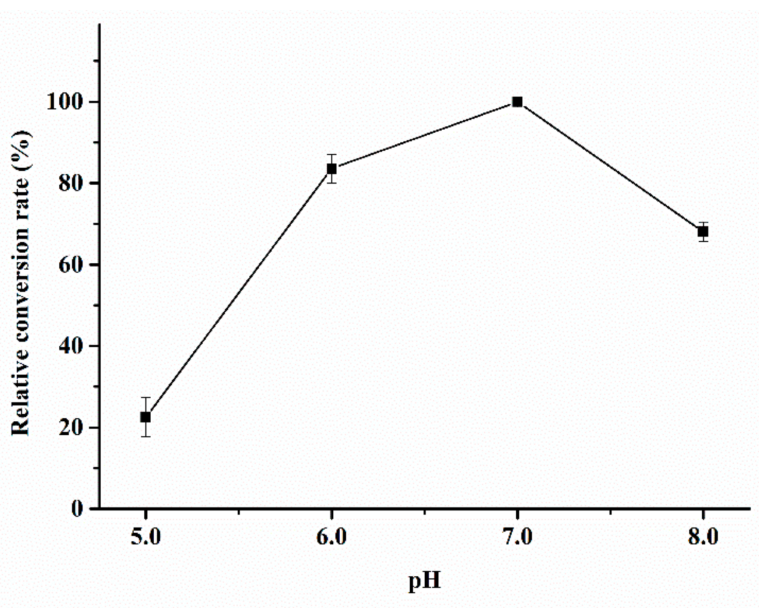

(A)

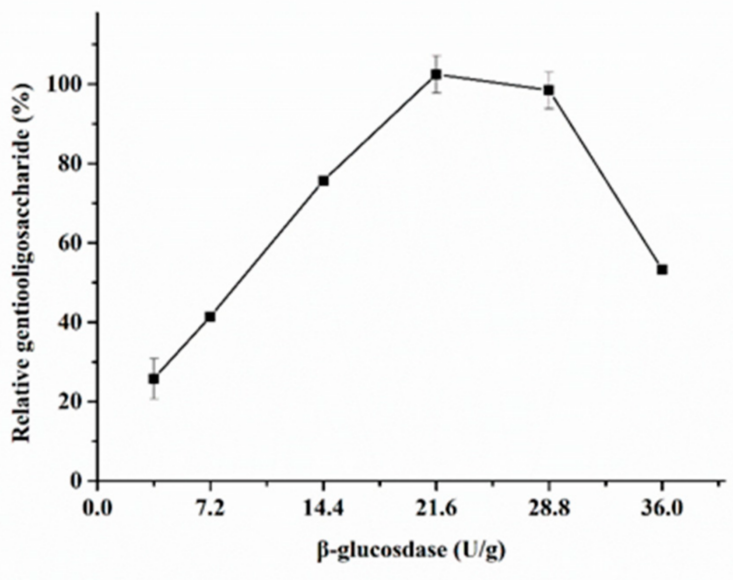

(B)

Figure 3. Effects of $\mathrm{pH}$ on the yield of gentiooligosaccharides (A). The reactions were performed at $40{ }^{\circ} \mathrm{C}$ in $0.2 \mathrm{M} \mathrm{McIlvaine}$ buffer for $\mathrm{pH} 3.0-8.0$ or $0.05 \mathrm{M}$ glycine- $\mathrm{NaOH}$ buffer for $\mathrm{pH} 8.0-11.0$ with 30\% glucose and $15 \%$ cellobiose. Outputs of gentiooligosaccharides at different concentration of Blg163 (B). The reactions were performed in optimum conditions.

Table 2. Effect of mass ratio of glucose and cellobiose on gentiooligosaccharide synthesis.

\begin{tabular}{|c|c|c|}
\hline Substrate Concentration & $\begin{array}{l}\text { Yields } \\
\left(\mathrm{g} \cdot \mathrm{L}^{-1}\right)\end{array}$ & $\begin{array}{c}\text { Conversion Rate } \\
(\%, w / w)\end{array}$ \\
\hline $60 \%$ glucose $+30 \%$ cellobiose & $51.21 \pm 4.41$ & $5.69 \pm 0.49$ \\
\hline $50 \%$ glucose $+25 \%$ cellobiose & $56.25 \pm 3.30$ & $7.50 \pm 0.44$ \\
\hline $40 \%$ glucose $+20 \%$ cellobiose & $63.00 \pm 6.70$ & $10.50 \pm 1.12$ \\
\hline $30 \%$ glucose $+15 \%$ cellobiose & $70.34 \pm 2.20$ & $15.63 \pm 0.49$ \\
\hline $25 \%$ glucose $+12.5 \%$ cellobiose & $40.39 \pm 2.51$ & $10.77 \pm 0.66$ \\
\hline $20 \%$ glucose $+10 \%$ cellobiose & $25.38 \pm 0.78$ & $8.46 \pm 0.26$ \\
\hline $10 \%$ glucose $+10 \%$ cellobiose & $9.02 \pm 0.42$ & $4.51 \pm 0.21$ \\
\hline $10 \%$ glucose $+20 \%$ cellobiose & $12.84 \pm 0.21$ & $4.28 \pm 0.07$ \\
\hline $5 \%$ glucose $+20 \%$ cellobiose & $12.88 \pm 0.50$ & $5.15 \pm 0.20$ \\
\hline
\end{tabular}

The optimal $\beta$-glucosidase enzyme concentration required for effective yield of gentiooligosaccharides was tested at $40^{\circ} \mathrm{C}$ and $\mathrm{pH} 7.0$ with a mixed substrate of glucose and cellobiose $(40 \%$ glucose $+20 \%$ cellobiose) (Figures $2 \mathrm{~B}$ and $3 \mathrm{~A})$. These results indicated that the yield of gentiooligosaccharides first improved with increase in the amount of the enzyme, peaked at $21.6 \mathrm{U} / 0.5 \mathrm{~g}$ glucose $/ \mathrm{g}$ cellobiose, followed by a gradual reduction. Hence, the optimum dosage of Blg163 was found to be $43.2 \mathrm{U} / 1.0 \mathrm{~g}$ glucose/g cellobiose, as shown in Figure 3B.

The synthesis of gentiooligosaccharides via reverse hydrolytic reactions requires nearly twice the amount of glucose and consumes more than 20-times the amount of $\beta$-glucosidase enzyme than transglycosylation. During the transglycosylation process, gentiooligosaccharides and glucose gradually accumulate and cellobiose is gradually deprived until the equilibrium point of the reaction is reached (Figures 4 and S5). The possible reason is that Blg163 has a lower affinity for gentiobiose than cellobiose, so it begins to degrade gentiobiose when the cellobiose is below the threshold, leading to a reduction in gentiooligosaccharides. With increase in reaction time, the yield of gentiooligosaccharides first increased, reached a peak after $48 \mathrm{~h}$, and then decreased gradually. Therefore, we conclude that an optimum time of $48 \mathrm{~h}$ was required for completion of the reaction. 


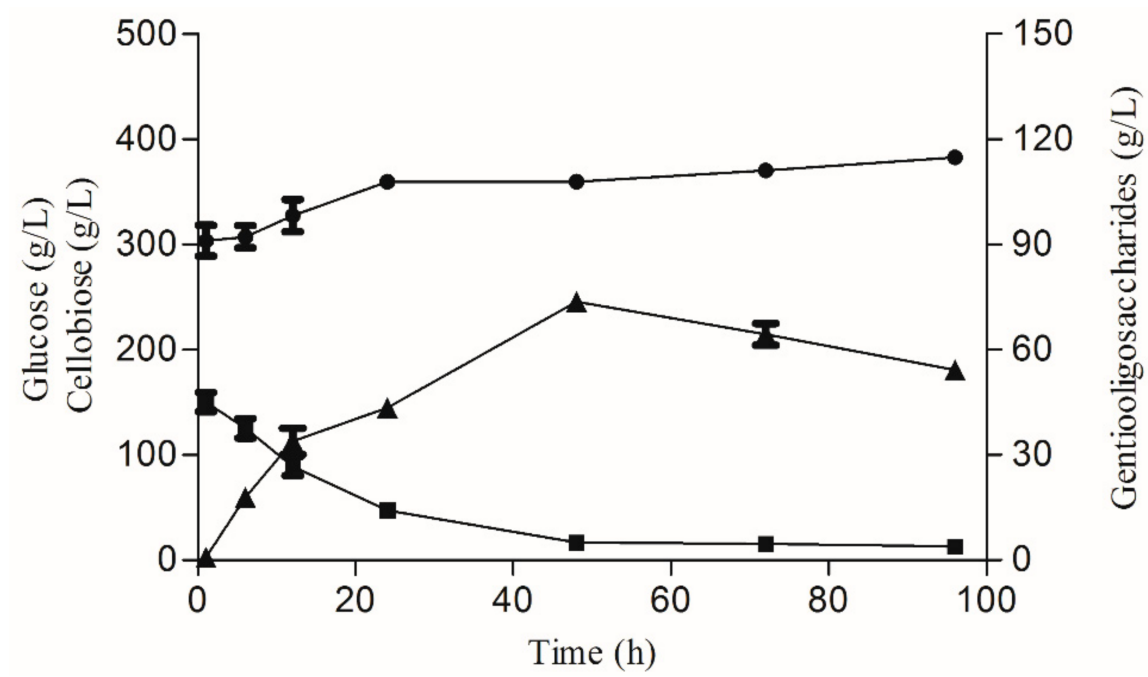

Figure 4. Time course of gentiobiose yield by the recombinant Blg163. The reactions were performed in optimum conditions. The HPLC analysis of the products formed by transglycosylation. (•) Glucose; (ם) cellobiose; ( $\mathbf{\Delta})$ gentiooligosaccharides.

\section{Conclusions}

This study identified a novel $\beta$-glucosidase gene, blg163, from the coral microbial metagenome which was successfully expressed in Escherichia coli BL21(DE3) pLysS. Blg163 exhibited a reasonable tolerance to glucose and ethanol, retaining $>40 \%$ activity in the presence of $5-20 \%$ glucose and $>50 \%$ in the presence of $15 \%$ ethanol. Using the reverse hydrolysis activity of Blg163 to synthesize gentiooligosaccharides, we showed that a peak yield of $43.02 \pm 3.20 \mathrm{~g} \cdot \mathrm{L}^{-1}$ and a conversion rate of $5.38 \pm 0.40 \%$, with glucose as a single substrate, could be achieved at $\mathrm{pH} 7.0$ and $40{ }^{\circ} \mathrm{C}$. We also synthesized gentiooligosaccharides via $\beta$-glucosidase-catalyzed transglycosylation with a mixed substrate of glucose and cellobiose. This process consumed $21.6 \mathrm{U} / 0.5 \mathrm{~g}$ glucose $/ \mathrm{g}$ cellobiose of $\beta$-glucosidase, achieving a yield of $70.34 \pm 2.20 \mathrm{~g} \cdot \mathrm{L}^{-1}$ and a conversion rate of $15.63 \%$. This is the mildest reaction and the lowest $\beta$-glucosidase consumption in gentiooligosaccharide synthesis from cellobiose and glucose reported to date.

\section{Patents}

There is a patent (NO. ZL 2020 10343911.X, China) resulting from the work reported in this manuscript.

Supplementary Materials: The following are available online at https://www.mdpi.com/article/10.339 0/foods10122985/s1, Figure S1: Stabilities of Blg163 under temperature; Figure S2: Stabilities of Blg163 under pH; Figure S3: Stabilities of Blg163 under glucose; Figure S4: Stabilities of Blg163 under ethanol; Figure S5: The gentiobiose production by the purified Blg163, The reactions were performed in $50 \mathrm{mM}$ citrate buffer ( $\mathrm{pH} 5.0$ ) at $40{ }^{\circ} \mathrm{C}$ with substrates ( $15 \%$ cellobiose and $30 \%$ glucose) and $21.6 \mathrm{U} / 0.5 \mathrm{~g}$ glucose/g cellobiose. 1. glucose; 2. cellobiose; 3 . Gentiobiose; $4-8$. product of different reaction; Table S1: Substrate specificity and Kinetic parameters of Blg163.

Author Contributions: Conceptualization, K.Y. and H.S.; methodology, Q.Z. and Z.X.; validation, H.S. and Q.Z.; formal analysis, Z.X.; investigation and data curation, Q.Z., C.L. and Z.X.; resources, Y.W., G.W., J.L., Q.H. and S.W.; writing — original draft preparation, H.S. and Q.Z.; writing—review and editing, H.S. and Q.Z.; project administration, K.Y. and H.S.; funding acquisition, K.Y. and H.S. All authors have read and agreed to the published version of the manuscript.

Funding: This work was supported by the National Natural Science Foundation of China (Nos. 42030502, 42090041, and 41706158), the Science and Technology Project of Guangxi (Nos. AD19245121, AD17129019, AD17129063, and AA17204074), the Major Research Project of Guangxi for Science and Technology (AA18242026), and the Natural Science Foundation of Guangxi Province (2018GXNSFBA281101). 
Conflicts of Interest: The authors declare no conflict of interest.

\section{References}

1. Kim, T.Y.; Lee, D.S.; Shin, H.J. Gentiobiose synthesis from glucose using recombinant $\beta$-glucosidase from Thermus caldophilus GK24. Biotechnol. Bioprocess Eng. 2003, 8, 210-212. [CrossRef]

2. Smaali, M.I.; Michaud, N.; Marzouki, N.; Legoy, M.D.; Maugard, T. Comparison of two $\beta$-glucosidases for the enzymatic synthesis of $\beta$-(1-6)- $\beta$-(1-3)-gluco-oligosaccharides. Biotechnol. Lett. 2004, 26, 675-679. [CrossRef] [PubMed]

3. Rycroft, C.E.; Jones, M.R.; Gibson, G.R.; Rastall, R.A. Fermentation properties of gentiooligosaccharides. Lett. Appl. Microbiol. 2001, 32, 156-161. [CrossRef]

4. Su, Z.; Luo, J.; Li, X.; Pinelo, M. Enzyme membrane reactors for production of oligosaccharides: A review on the interdependence between enzyme reaction and membrane separation. Sep. Pur. Technol. 2020, 243, 116840. [CrossRef]

5. Gibson, G.R.; Roberfroid, M.B. Dietary modulation of the human colonic microbiota: Introducing the concept of prebiotics. J. Nutr. 1995, 125, 1401-1412. [CrossRef] [PubMed]

6. Wang, F.; Wu, J.; Chen, S. Preparation of gentiooligosaccharides using Trichoderma viride beta-glucosidase. Food Chem. 2018, 248, 340-345. [CrossRef] [PubMed]

7. Fujimoto, Y.; Hattori, T.; Uno, S.; Murata, T.; Usui, T. Enzymatic synthesis of gentiooligosaccharides by transglycosylation with beta-glycosidases from Penicillium multicolor. Carbohydr. Res. 2009, 344, 972-978. [CrossRef]

8. Kono, H.; Kawano, S.; Tajima, K.; Erata, T.; Takai, M. Structural analyses of new tri- and tetrasaccharides produced from di-saccharides by transglycosylation of purified Trichoderma viride $\beta$-glucosidase. Glycoconj. J. 1999, 16, 415-423. [CrossRef]

9. Park, T.-H.; Choi, K.-W.; Park, C.-S.; Lee, S.-B.; Kang, H.-Y.; Shon, K.-J.; Park, J.-S.; Cha, J. Substrate specificity and transglycosylation catalyzed by a thermostable $\beta$-glucosidase from marine hyperthermophile Thermotoga neapolitana. Appl. Microbiol. Biotechnol. 2005, 69, 411-422. [CrossRef]

10. Chang, J.; Park, I.H.; Lee, Y.S.; Ahn, S.C.; Zhou, Y.; Choi, Y.L. Cloning, expression, and characterization of $\beta$-glucosidase from Exiguobacterium sp. DAU5 and transglycosylation activity. Biotechnol. Bioprocess Eng. 2011, 16, 97-106. [CrossRef]

11. Qin, Y.; Zhang, Y.; He, H.; Zhu, J.; Chen, G.; Li, W.; Liang, Z. Screening and identification of a fungal beta-glucosidase and the enzymatic synthesis of gentiooligosaccharide. Appl. Biochem. Biotechnol. 2011, 163, 1012-1029. [CrossRef]

12. Yang, S.; Hua, C.; Yan, Q.; Li, Y.; Jiang, Z. Biochemical properties of a novel glycoside hydrolase family 1 beta-glucosidase (PtBglu1) from Paecilomyces thermophila expressed in Pichia pastoris. Carbohydr. Polym. 2013, 92, 784-791. [CrossRef]

13. Guo, Y.; Yan, Q.; Yang, Y.; Yang, S.; Liu, Y.; Jiang, Z. Expression and characterization of a novel beta-glucosidase, with transglycosylation and exo-beta-1,3-glucanase activities, from Rhizomucor miehei. Food Chem. 2015, 175, 431-438. [CrossRef]

14. Ketudat, C.J.; Esen, A. ß-Glucosidases. Cell. Mol. Life Sci. CMLS 2010, 67, 3389-3405. [CrossRef]

15. Hu, Y.; Luan, H.; Zhou, K.; Ge, G.; Yang, S.; Yang, L. Purification and characterization of a novel glycosidase from the china white jade snail (Achatina fulica) showing transglycosylation activity. Enzy. Microb. Technol. 2008, 43, 35-42. [CrossRef]

16. Ahmed, A.; Nasim, F.H.; Batool, K.; Bibi, A. Microbial $\beta$-Glucosidase: Sources, Production and Applications. J. Appl. Environ. Microb. 2017, 5, 31-46. [CrossRef]

17. Bourne, D.G.; Morrow, K.M.; Webster, N.S. Insights into the coral microbiome: Underpinning the health and resilience of reef ecosystems. Annu. Rev. Microb. 2016, 70, 317-340. [CrossRef]

18. Yoshioka, Y.; Tanabe, T.; Iguchi, A. The presence of genes encoding enzymes that digest carbohydrates in coral genomes and analysis of their activities. PeerJ 2017, 5, e4087. [CrossRef] [PubMed]

19. Titlyanov, E.A.; Titlyanova, T.V.; Leletkin, V.A.; Tsukahara, J.; Van, W.R.; Yamazato, K. Degradation of zooxanthellae and regulation of their density in hermatypic corals. Mar. Ecol. Prog. Ser. 1996, 139, 167-178. [CrossRef]

20. Krediet, C.J.; Ritchie, K.B.; Teplitski, M. Catabolite regulation of enzymatic activities in a white pox pathogen and commensal bacteria during growth on mucus polymers from the coral Acropora palmata. Dis. Aquat. Org. 2009, 87, 57-66. [CrossRef]

21. Su, H.; Xiao, Z.; Yu, K.; Huang, Q.; Wang, G.; Wang, Y.; Chen, B. Diversity of cultivable protease-producing bacteria and their extracellular proteases associated to scleractinian corals. PeerJ 2020, 8, e9055. [CrossRef] [PubMed]

22. Eberhart, B.; Cross, D.F.; Chase, L.R. Beta-glucosidase system of Neurospora crassa I beta-glucosidase and cellulase activities of mutant and wild-type strains. J. Bacteriol. 1964, 87, 761-770. [CrossRef]

23. Bradford, M.M. A rapid and sensitive method for the quantitation of microgram quantities of protein utilizing the principle of protein-dye binding. Anal. Biochem. 1976, 72, 248-254. [CrossRef]

24. Mai, Z.; Yang, J.; Tian, X.; Li, J.; Zhang, S. Gene cloning and characterization of a novel salt-tolerant and glucose-enhanced beta-glucosidase from a marine Streptomycete. Appl. Biochem. Biotechnol. 2013, 169, 1512-1522. [CrossRef]

25. Odoux, E.; Escoute, J.; Verdeil, J.L.; Brillouet, J.M. Localization of $\beta$-D-glucosidase activity and glucovanillin in vanilla bean (Vanilla planifolia Andrews). Annal. Botany 2003, 92, 437-444. [CrossRef]

26. Jo, Y.Y.; Jo, K.J.; Jin, Y.L.; Kim, K.Y.; Shim, J.H.; Kim, Y.W.; Park, R.D. Characterization and kinetics of 45 kDa chitosanase from Bacillus sp. P16. Biosci. Biotechnol. Biochem. 2003, 67, 1875-1882. [CrossRef]

27. Waterhouse, A.; Bertoni, M.; Bienert, S.; Studer, G.; Tauriello, G.; Gumienny, R.; Schwede, T. SWISS-MODEL: Homology modelling of protein structures and complexes. Nucl. Acids Res. 2018, 46, W296-W303. [CrossRef] [PubMed]

28. Robert, X.; Gouet, P. Deciphering key features in protein structures with the new ENDscript server. Nucl. Acids Res. 2014, 42, W320-W324. [CrossRef] 
29. Hao, S.; Liu, Y.; Qin, Y.; Zhao, L.; Zhang, J.; Wu, T.; Wang, C. Expression of a highly active $\beta$-glucosidase from Aspergillus niger AS3.4523 in Escherichia coli and its application in gardenia blue preparation. Annal. Microbiol. 2020, 70, 1-9. [CrossRef]

30. Liu, L.; Zhu, S.; Zhu, T.; Zhang, M.; Wu, J.; Chen, J. Production of gentiooligosaccharide by recombinant beta-glucosidase. Wei Sheng Wu Xue Bao Acta Microbiol. Sini. 2009, 49, 597-602.

31. He, H.; Qin, Y.; Chen, G.; Li, N.; Liang, Z. Two-Step purification of a novel $\beta$-glucosidase with high transglycosylation activity and another hypothetical $\beta$-glucosidase in Aspergillus oryzae HML366 and enzymatic characterization. Appl. Biochem. Biotechnol. 2013, 169, 870-884. [CrossRef] [PubMed]

32. Ramani, G.; Meera, B.; Rajendhran, J.; Gunasekaran, P. Transglycosylating glycoside hydrolase family $1 \beta$-glucosidase from Penicillium funiculosum NCL1: Heterologous expression in Escherichia coli and characterization. Biochem. Eng. J. 2015, 102, 6-13. [CrossRef]

33. Seidle, H.F.; Huber, R.E. Transglucosidic reactions of the Aspergillus niger Family $3 \beta$-glucosidase: Qualitative and quantitative analyses and evidence that the transglucosidic rate is independent of pH. Arch. Biochem. Biophys. 2005, 436, 254-264. [CrossRef] [PubMed]

34. Seidle, H.F.; Allison, S.J.; George, E.; Huber, R.E. Trp-49 of the family $3 \beta$-glucosidase from Aspergillus niger is important for its transglucosidic activity: Creation of novel $\beta$-glucosidases with low transglucosidic efficiencies. Arch. Biochem. Biophys. 2006, 455, 110-118. [CrossRef] 